\title{
SOCIAL CAPITAL AND MIGRANTS' POLITICAL INTEGRATION: THE CASE STUDY OF CAPEVERDEAN ASSOCIATIONS IN THE GREATER LISBON AREA ${ }^{1}$
}

\author{
Ana Paula Beja Horta ${ }^{2}$ \\ JORGE MALHEIROS ${ }^{3}$
}

\begin{abstract}
This paper analyses the types of social capital present in the Capeverdean associational movement of the Greater Lisbon Area (GLA) and its relation to political involvement and mobilization. The notion of social capital («features of social organization such as networks, norms and social trust that facilitate coordination and co-operation for mutual benefit» - Putnam, 1993: 26) is explored in its two basic components - bonding (internal links of individuals and institutions) and bridging social capital (external connections, that also entail the long distance relations with the other diaspora nuclei) -, following the research principles expressed in the work of Fennema and Tillie $(2000,2001)$.

The research goals are achieved through interviews and questionnaires to the major Capeverdean associations of Lisbon, Amadora and Oeiras, focusing on its organizational structure and on the density of their organizational network, that is the web of inter and intra-organizational relations and transnational links that might be read as forms of bridging and bonding social capital. We also focussed on the political activities of organisations, looking at ethnic civic engagement and exploring the extent to which social trust in the form of social capital is converted into political involvement.

Major results show that associations of Oeiras and Amadora are mainly grassroots based organisations that privilege neighbourhood-bonding ties, whereas Lisbon's associations assume a structural/"umbrella-like" role in the institutional Capeverdean fabric. In addition, the density of institutional relations is much higher at the internal level (with other Capeverdean organisations) than at the external level. The exception concerns the relevance of the international links with other Capeverdean associations. Finally, the findings show that associations with higher social capital that is with the densest network of organizational relations are also those that participate more actively in political activities.
\end{abstract}

Key words: Capeverdean associations, social capital, political participation.

1 Greater Lisbon Area (GLA) corresponds to the nine municipalities of the North Bank that integrate the Lisbon Metropolitan Area.

2 Centro de Estudos das Migrações e Relações Interculturais (CEMRI) da Universidade Aberta, Lisboa. Email: apbhorta@univ-ab.pt

3 Professor Associado do Departamento de Geografia da Faculdade de Letras da Universidade de Lisboa e Investigador do Centro de Estudos Geográficos. Email: gatomaltes@netcabo.pt 
Resumo - CAPITAL SOCIAL E INTEGRAÇÃO POLÍTICA DE MIGRANTES: O ESTUDO DE CASO DAS ASSOCIAÇÕES CABO-VERDIANAS NA ÁREA DA GRANDE LISBOA. Este artigo analisa as formas de capital social presentes no tecido associativo cabo-verdiano de alguns municípios da Grande Lisboa, procurando relacioná-las com as capacidades de intervenção e mobilização política. A dimensão relacional do capital social («características da organização social como redes, normas e relações de confiança, que facilitam as formas de coordenação e cooperação para benefício mútuo» - Putnam, 1993: 26) é explorada nas suas duas componentes básicas - ligações de proximidade/vizinhança (ligações internas entre indivíduos e/ou instituições) e ligações à distância (relações externas, que incluem as ligações internacionais com outros núcleos da diáspora) segundo o quadro analítico-conceptual proposto por Fennema e Tillie $(2000,2001)$.

Os objectivos da investigação são atingidos através da aplicação de entrevistas e questionários às principais associações cabo-verdianas dos concelhos de Oeiras, Amadora e Lisboa, relativos à sua estrutura organizativa, à densidade das suas redes intra- e interrelacionais e às suas ligações transnacionais, podendo todas estas dimensões ser interpretadas no âmbito das duas componentes do capital social. A investigação centra-se, igualmente, nas actividades políticas das associações, conferindo particular atenção à participação cívica de base étnica e procurando perceber até que ponto a confiança social, entendida enquanto capital social, pode ser convertida em participação política.

Os resultados da investigação mostram que as associações da Amadora e de Oeiras têm um carácter mais "basista", privilegiando as relações de proximidade ao nível local. Já as associações de Lisboa assumem uma função de "chapéu" ao nível do tecido institucional cabo-verdiano. Adicionalmente, as relações internas das associações (com outras organizações cabo-verdianas) são bastante mais intensas do que as relações externas, constituindo excepção as relações internacionais com outras organizações da diáspora cabo-verdiana. Por último, os resultados evidenciam também que as associações com maior nível de capital social, isto é, com maior densidade relacional, são também aquelas que revelam maiores índices de participação política.

Palavras-chave: Associações cabo-verdianas, capital social, participação
política.

Résumé - CAPITAL SOCIAL ET INTÉGRATION POLITIQUE DES ÉMIGRANTS: ÉTUDE DU CAS DES ASSOCIATIONS DE CAP-VERDiENS DANS La GRANDE LisBonne. On analyse les formes de capital social présentes dans le tissu associatif cap-verdien de quelques communes de la Grande Lisbonne, en les mettant en rapport avec les capacités d'intervention et de mobilisation politiques. La dimension relationnelle du capital social («les caractéristiques d'organisation sociale, telles que réseaux, normes et relations de confiance, facilitant les formes de coordination et de coopération en vue d'un bénéfice mutuel»-Putnam, 1993: 26) est étudiée dans ses deux composantes de base: les liens de proximité/voisinage (liens internes, entre individus et/ou institutions) et liens à distance (relations externes, y compris les liens internationaux avec d'autres foyers de la diaspora), d'après le cadre analitico-conceptuel proposé par Fennema et Tillie (2000, 2001).

La recherche a été conduite en proposant aux principales associations capverdiennes des concelhos de Oeiras, Amadora et Lisbonne des entrevues et des questionnaires sur leur organisation, sur la densité de leurs réseaux internes et externes et sur leurs relations internationales, de façon à permettre l'interprétation de ces caractéristiques dans le cadre des deux composantes du capital social. On a surtout étudié les activités politiques des associations, en portant une attention particulière 
à la participaton civique de base ethnique et en cherchant à comprendre dans quelle mesure la confiance sociale, entendue comme capital social, peut se transformer en intervention politique.

On montre que les associations de Amadora et de Oeiras privilégient surtout les relations de proximité, au niveau local. Par contre, celles de Lisbonne assument une fonction de coordination du réseau institutionnel cap-verdien. Les relations internes des associations (avec les autres organisations congénères) sont plus intenses que les relations externes, à l'exception des relations internationales avec d'autres organisations de la diaspora cap-verdienne. On montre enfin que les associations dont le niveau de capital social est le plus élevé, à cause d'une plus forte densité relationnelle, sont aussi celles qui ont les plus forts indices de participation politique.

Mots-clés: Associations cap-verdiennes, capital social, participation politique.

\section{INTRODUCTION}

In the last decades, the political integration of migrants has become a key issue in contemporary democracies. The need to address current inequalities and a growing democratic deficit in regards to the political rights of immigrants and ethnic minorities has been at the heart of a long-lasting debate on ethnic civic participation and its effects on the integration of ethnic minorities. Nowadays, political observers - from liberals to radical democrats and libertarians - see ethnic civic engagement as a major factor for the functioning of a ethnically diverse truly democratic society.

Across Europe, the granting of local voting rights and the creation of other formal and informal mechanisms to enhance the political participation of minority groups are seen as important integration measures. In broad terms, Western countries have extended most civil rights to non-nationals and a similar pattern has also been identified in the case of social rights. In the majority of European immigration countries, legal residents have, in the last decade, gained access to welfare benefits and public social assistance provisions. By contrast, the allocation of political rights (the right to vote and to be elected) to nonnationals has varied significantly from country to country. For instance, in Sweden and the Netherlands local voting rights to national foreigners were granted in 1976 and 1985 respectively, whereas in Germany third country nationals have no voting rights and in Switzerland only three cantons have introduced such rights. In recent immigration countries such as Spain and Portugal, local voting rights to foreign nationals were granted only in the late 1990s (Horta and Matés, 2005) and, in the latter case, these have even subjected to a reciprocity demand ${ }^{4}$.

4 As far as Portugal is concerned, the right to vote in Portuguese local elections is only given to non-EU citizens coming from countries that also allow Portuguese citizens to vote in their own local elections. 
Nation-states have, thus, adopted different paths of incorporation of migrant population in the political sphere, according to distinct modes of national membership. For Soysal (1994), these are characterized by "corporatist" policies; in the case of Sweden and the Netherlands; a mixed "statist-corporatist" model in Germany, a "centralized-individualist" approach in France and finally an "individualist" liberal approach in Switzerland and Britain. Furthermore, Soysal suggests that host societies' institutional settings are of crucial importance in accounting for migrants' organizing and political activism. That is, migrants' organizational forms, goals, political tactics, and strategies, as well as levels of integration and participation in the host society, reflect the nature of states' incorporation policies. From a different perspective, Koopmans and Statham (2000) propose a "political opportunity approach" to the study of minority groups and the political community. Drawing on social movements theory and by focussing on the political claims-making of minority groups, the authors suggest that the nature of ethnic mobilization is very much dependent on the degree of inclusiveness (or exclusiveness) of the political structure. National integration policies and citizenship regimes are found to be of significance in explaining different patterns of migrants' political incorporation.

At a local level, in the 1990s, a wide range of consultative bodies and other institutional mechanisms for foreigners have been created throughout Europe. Still, the participatory frameworks vary from city to city and new social and cultural dividing lines have emerged between immigrant populations and the city they live in. The reasons underlying the creation of institutional consultative bodies are multiple and much diversified. Their effectiveness has been the source of a heated debate and controversy. For some, these new participation channels are often perceived as means to neutralize immigrants and ethnic minority claims for voting rights, as a symbolic gesture to promote social cohesion and harmony or even as an institutional channel for the articulation of migrants claims-making (Anderson, 1990; Vertovec, 1999).

Local policies and migrants' collective mobilization in European cities have been at the object of ever-increasing cross-national and cross-local scientific work. For instance, Bousetta's work (1997) on Moroccan community political activism in Lille in France and Utrecht in the Netherlands shows how citizenship frameworks condition the political opportunities of migrant ethnic communities. According to Bousetta, Moroccans' organizational structure and political strategies differ considerably in the two local contexts. While in the Netherlands, policy frameworks have promoted political mobilization in terms of ethnic identity issues, in France institutional structures tend to constrain the manipulation of ethnicity as a resource for collective action. Drawing on claims-making approach, Koopmans and Statham (2000) propose a "political opportunity approach" to the study of minority groups and the political community. The authors contend that the nature of ethnic mobilization is very much dependent on the degree of inclusiveness (or exclusiveness) of the political structure. National integration policies and citizenship regimes are found 
to be of significance in explaining different patterns of migrants' political incorporation ${ }^{5}$.

The work of these authors brings valuable insights to the debate on citizenship and migrants' political incorporation. Yet, these studies tend to underplay the dynamics of migrants' associational formation, strategies, goals and its impact on political participation at the local level. A call for more empirically grounded research on the nature of ethnic organizational formation has been stressed by several authors as a means of redressing the interplay between ethnic social capital and political integration.

Drawing on Fennema and Tillie's ethnic social capital approach, combined with elements coming from the approaches of other authors such as Baernholdt and Aarsother (2002), this paper presents the preliminary findings of a research project currently underway in Lisbon ${ }^{6}$. It aims at exploring the link between the social capital of Capeverdean associational movement and the degree and modes of their political involvement in some municipalities of the Greater Lisbon Area (GLA), the major concentration area of this population in Portugal. The main hypothesis is that the level of social capital of an ethnic group has a positive impact on migrants' political integration.

The study the Capeverdean ethnic group has to do with the fact that it is the oldest and the largest immigrant community residing in the country and, secondly, it has a well-established network of associations, the majority of which are concentrated in the Metropolitan Area of Lisbon, more specifically in the municipalities of Lisbon, Amadora and Oeiras. What follows is an overview of the issues being raised by our empirical research. In the first part, the theoretical research design will be discussed in light of Baernholdt and Aarsother (2002) concepts of bonding and bridging capital and Fennema and Tillie's (1999) ethnic civic community approach to ethnic groups' political participation. In the second part, the presentation of findings will address the level of social capital of Capeverdean associations focussing on two main dimensions: the organizational structure and the social capital of associations in terms of the density of its networks within the community and outside it. Finally, we will report on the nature of the group's political activities.

\section{SOCIAL CAPITAL AND POLITICAL PARTICIPATION}

The social capital approach to the functioning of democratic institutions has gained a new impetus in social research. The work of Putnam $(1993,2000)$

5 See the work of Penninx et. al. (2004) on citizenship, local policies and social integration of migrant communities in European cities.

6 The research conducted in Lisbon is part of an international research network Multicultural Democracy in European Cities. Political Integration, Communities and Local Policies, coordinated by the University of Amsterdam, Institute of Migration and Ethnic Studies. The network is engaged on a cross-national comparative study of political participation of migrant communities in 12 European cities. 
on regional inequalities in Italy brought to the fore a wide discussion on social capital. According to Putnam, the effectiveness of political institutions is very much dependent on the nature of the civic community. The social capital that is embedded in the civic community is perceived as an important predictor of social trust and civic engagement. Drawing on Bourdieu's notion of social capital, Putnam (1993: 26) provides a conception of social capital that «refers to features of social organization such as networks, norms and social trust that facilitate coordination and cooperation for mutual benefit».

As mentioned in the World Bank website, «Social Capital is not just the sum of institutions which underpin a society - it is the glue that holds them together». Institutional thickness, network and network efficiency, social norms and reciprocal trust are key elements to evaluate the levels of social capital existing in a society or in a community.

The main idea is that the social networks of individuals and their commitment to society have a positive effect on the social, economic, political and cultural development of societies. More recently, Putnam (2000) argues that in the case of the USA, the erosion of social bonds and a weak commitment to the community has undermined the functioning of democracy.

Considering the contemporary feature of international migration, it becomes clear that the social capital concept can be a key instrument of analysis, providing new and encompassing approaches. Actually, migration options and local insertion strategies largely rely on the framework of social networks of acquaintances and relatives as well as on the action of the fabric of institutional representatives of immigrants, from political parties to socio-cultural associations. While applying this conceptual approach to the analysis of immigrants and immigrants' institutional networks, the two basic dimensions ("bonding capital" and "bridging capital") considered by Baernholdt and Aarsother (2002) might be of great usefulness. If the "bonding capital" corresponds to the internal links (and associated set of norms and trustfulness) of the individuals and organisations and the "bridging ties" to the external connections of those, it is legitimate to suppose that the sustainability and the community reproduction of the migrant groups depend, simultaneously on the level of embeddedness in those two kinds of networks: the intra-group one and the extra-group + transnational one. In this sense, bonding capital refers to vicinity/short distance ties (inside the immigrant group but also with the nonethnic neighbours), while bridging social capital is associated i) to the ties with the individual and institutional representatives of the majority society and also of other ethnic groups (bridging I) and ii) to the long distance relations established with the members of the ethnic group which are scattered in other places of the world (bridging II). Having these last features in consideration, this concept of social capital increases its potential added value when used in the process of analysis of transnational communities, such as the Capeverdean one.

The relevance of social capital in the scope of the heightened awareness of social networks is evident in the emergent approach of political participation and ethnic civic society (Fennema and Tillie, 1999, 2001). Here the focus is on how 
ethnic associations are connected to and embedded in a web of relations which tends to increase social trust and, ultimately, political participation. Central to the theoretical approach of Fennema and Tillie (20010) is the idea that the strength of the ethnic civil community is an important predictor of migrants' political involvement. This notion draws heavily on the concept of civic community as «a set of interrelated civic organisations. These civic organisations may be related through overlapping membership or through interlocking at the elite level» (Fennema, 2004: 432). The assumption is that the denser the networks among ethnic organisations, the stronger the ethnic civic community is and the higher the social capital at a group level. If the ethnic organisations show a high degree of connection among themselves, their members have higher access to a multiplicity of resources which otherwise would not be available if the network is fragmented. To this extent, the density of the connections between ethnic organisations and between them and other organisations tend to promote social trust and strength the cohesion among ethnic organisations and the communication efficacy of ethnic leaders.

In their research on political participation of ethnic communities in Amsterdam and in other cities, the authors identified a link between the network of ethnic associations and the degree of political participation and political trust. The comparative study of Turks, Moroccans, Surinamese and Antilleans in Amsterdam have shown that for instances Turks who have a denser network of associations in Amsterdam than Moroccans are also the group who scored higher in political trust and political participation. The link between social capital embedded in associations' networks, political trust and political participation was also found in the study of Surinamese and Antilleans. These findings tend to support the hypothesis that the denser the networks between ethnic organisations, the higher their social capital and social trust. Furthermore, such trust is not limited to the social milieus of ethnic organisations but it has also a positive effect on political trust and political participation.

Drawing on this model, this paper will focus especially on the organizational structure, the density of the organisations' networks and political activities.

\section{THE CAPEVERDEANS IN THE REGION OF LISBON}

Capeverdeans are the oldest group of labour migrants in the Portuguese society. The first Capeverdean workers settled in Portugal in the second half of the 1960s, when certain activity sectors (construction and public works) experienced labour shortages due to the emigration of national population and also to the size of the army involved in the colonial wars in Africa. Most of the migrants associated to this first wave have settled in the Lisbon Metropolitan Area, not only in the municipalities of the GLA (North Bank of Tagus) but also in the South Bank. In those early days of Capeverdean migration, an area of the inner city close to the harbour (São Bento-Santos) has become a major settlement place and a social reference to the Capeverdean community. 


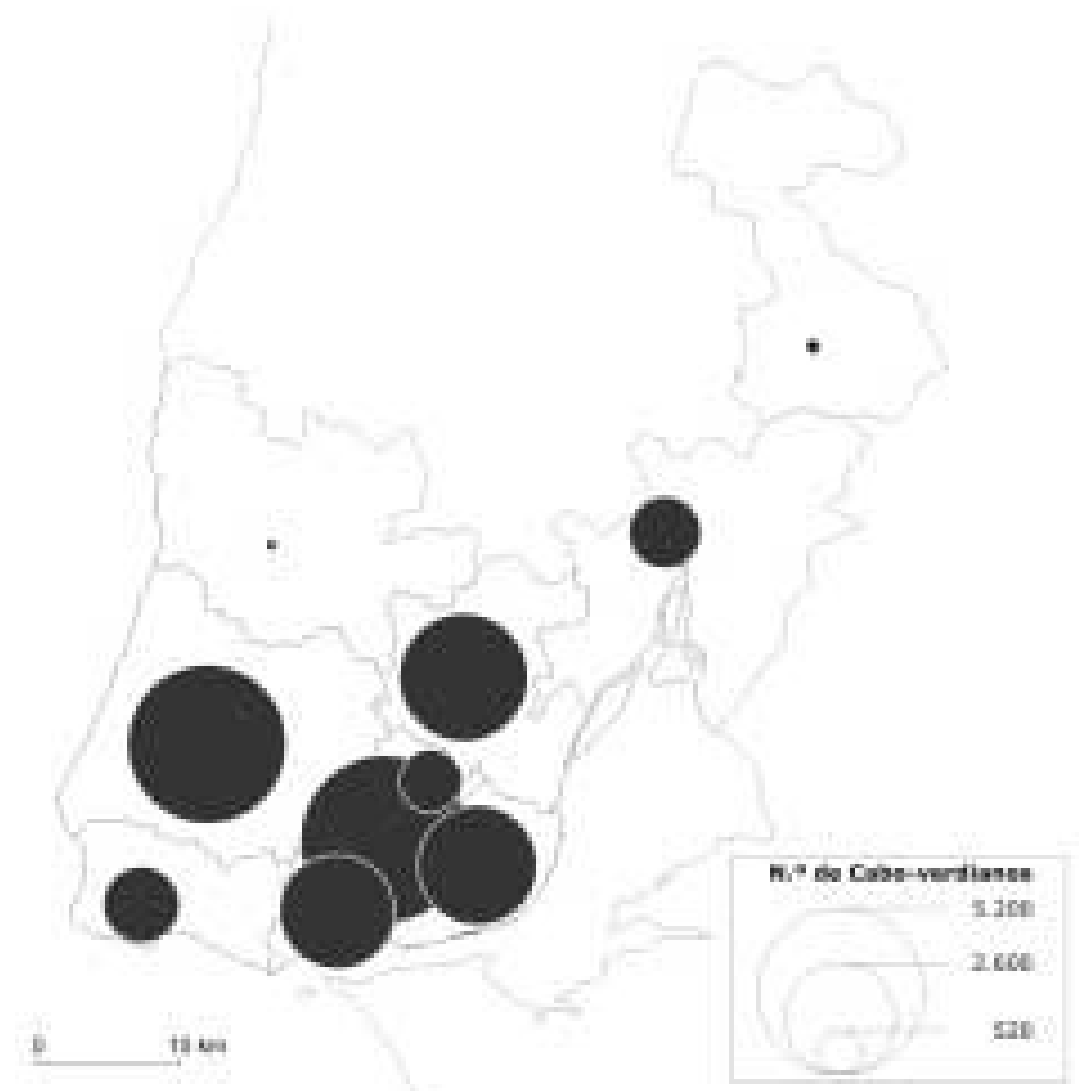

Fig. 1 - Capeverdean nationals in the municipalities of Greater Lisbon, 2001.

Fig. 1 - Cabo-verdianos residentes nosmunicipios da Grande Lisboa, 2001.

SourCE: INE, Census 2001

However, progressively a significant number of Capeverdean migrants started to settle in the outskirts of Lisbon, especially in the first metropolitan ring (e.g. municipalities of Oeiras and Amadora), where land prices were cheaper, the opportunities for the construction of clandestine housing were higher and the distance to the working places (the construction yards) more reduced. In fact, upon arrival, many immigrants lived in the construction yards.

The geographical pattern of peripheral location of Capeverdeans has become more consolidated in the mid-1970s, with the booming of arrivals in the context of the decolonisation (Horta and Malheiros, 2004). A large number of these people have found residence in shack settlements or in the clandestine housing neighbourhoods of the peripheries, where free space was available and where official mechanisms of land control and land regulation were weaker or ineffective.

This pattern of over-representation in slum areas and public housing estates in the municipalities of the first peripheral ring has been reproduced in the 1980s and 1990s. Newcomers arriving as labour migrants or family members have frequently settled in the neighbourhoods where Capeverdeans were more concentrated due to the role of the social support networks of relatives and country-fellows (Malheiros and Vala, 2004). The result of this 


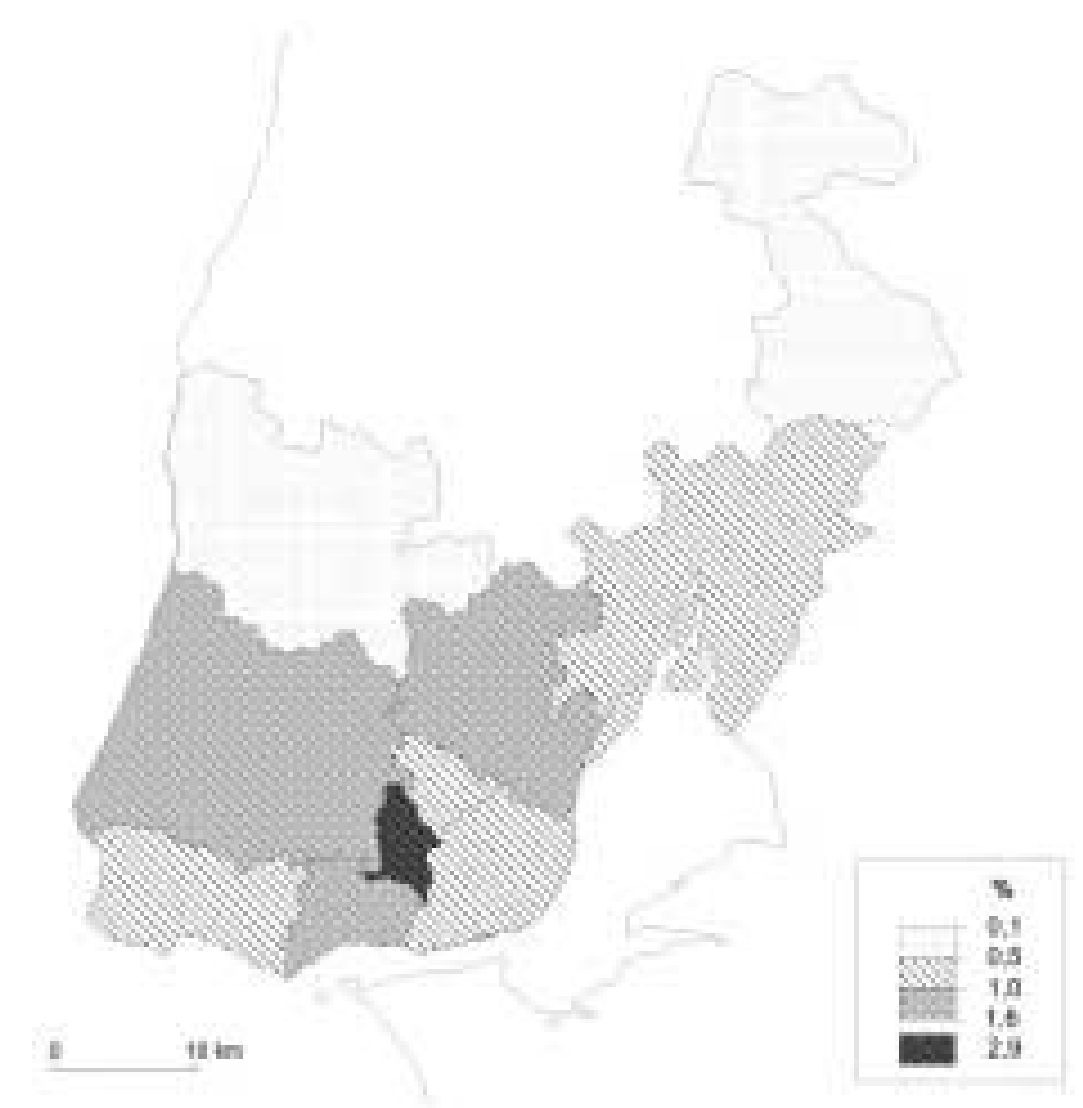

Fig. 2 - Percentage of Capeverdean nationals in the total number of residents in the municipalities of Greater Lisbon, 2001.

Fig. 2 - Percentagem de nacionais cabo-verdianos no total da população residente nos municípios da Grande Lisboa, 2001.

SOURCE: INE, Census 2001

process has led to a concentration of Capeverdeans in the municipalities of Lisbon, Amadora, Oeiras, Loures and Sintra (fig.1), being the relative weight clearly higher in the suburban municipalities, with particular emphasis in Amadora (fig.2). The important number of Capeverdeans living in the municipality of Sintra, which has become a transition area between the first metropolitan ring and the second metropolitan ring, is largely associated to the urban and demographic recomposing process of the Lisbon Metropolitan Area. In fact, Sintra is the municipality in the whole country with the highest population growth rates of the 1990 s, displaying a very significant housing supply at relatively low cost that has attracted many young residents. Several Capeverdeans who experienced an income increase after some years of residence in the GLA and want to move out from slum neighbourhoods have bought or rented flats in the concelho of Sintra.

If we take into consideration only the foreigners living in the Greater Lisbon municipalities, Capeverdeans are the most numerous group, with an effective of approximately 22.000 individuals that correspond to a little more than $1 \%$ of the total resident population and to more than $20 \%$ of the foreigners (Census, 
2001). However, if one takes into account the people of Capeverdean origin who have obtained Portuguese citizenship and the children already born in Portugal, the numbers would certainly double (Embaixada de Cabo Verde em Portugal/IESE/Geoideia, 1999).

Due to their early presence in the first metropolitan ring, particularly in some neighbourhoods of Amadora and Oeiras where Capeverdeans have established, throughout the years, strong informal networks that contribute to the reproduction of the community in situ, they are clearly over-represented in these 2 municipalities, corresponding to more than $1 / 3$ of the foreigners (fig.3).

The history of the community in these two places, its visibility and its absolute and especially relative importance justify the choices of Amadora and Oeiras as case studies. The inclusion of Lisbon is less associated to the absolute or relative importance of the settled community than to the relevance of the Capeverdean institutional fabric, especially when core associations are considered.

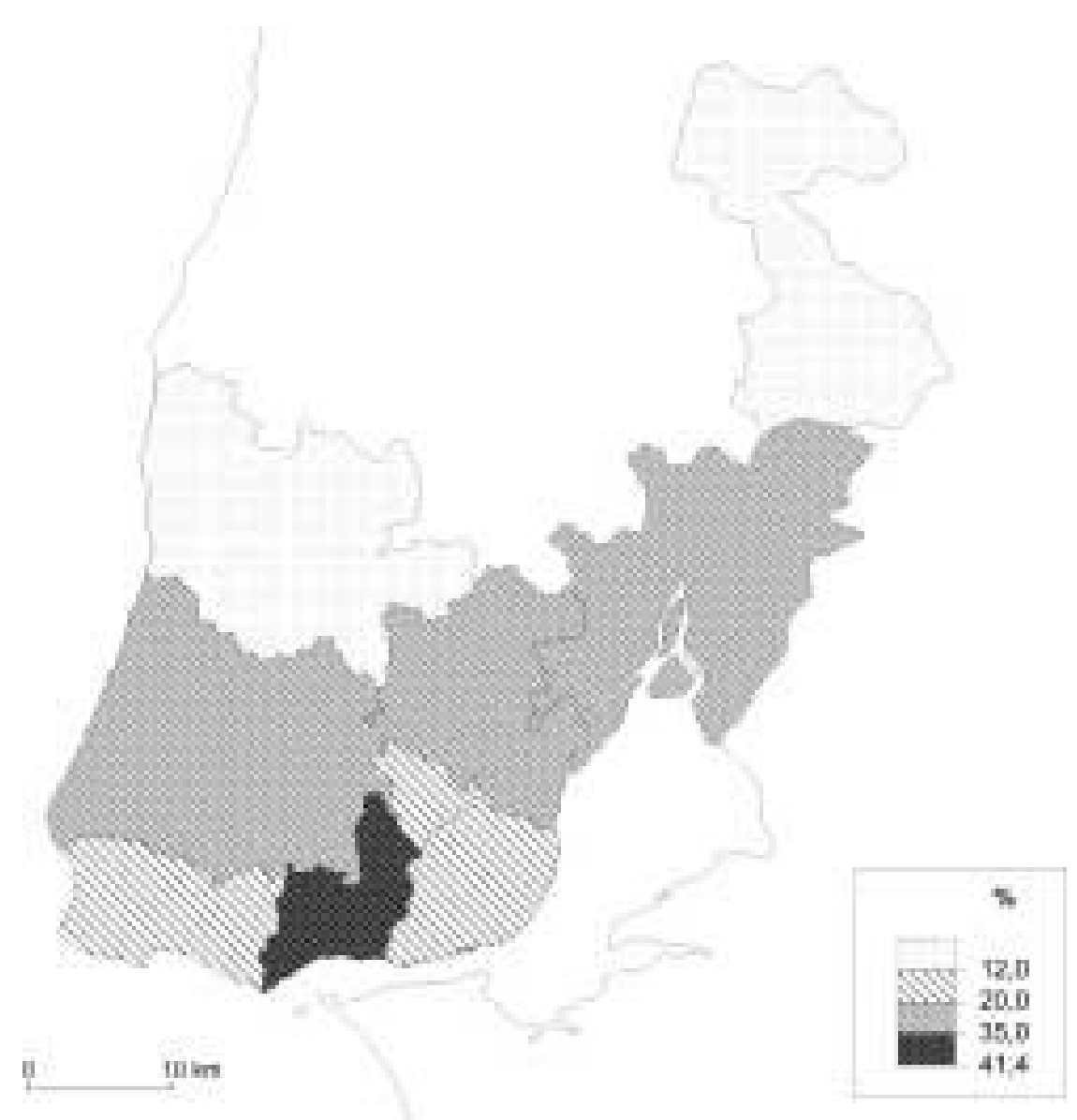

Fig. 3 - Percentage of Capeverdean nationals in the total number of foreigners in the municipalities of Greater Lisbon, 2001.

Fig. 3 - Percentagem de nacionais cabo-verdianos no total de estrangeiros residentes nos municípios da Grande Lisboa, 2001. 


\section{DATA COLLECTION}

The data for this study was collected from May to September 2004, using three major sources: 1. bibliographical materials (statistics, policy documents, institutional information, migrants' organization reports, etc); 2. a local organizational questionnaire to study the characteristics, activities and networks of migrant organisations; and 3. a set of interviews with local officials and policy makers.

The objective was to apply the organizational questionnaire to all the Capeverdean associations operating in the GLA. Yet, scarcity of resources and time constraints prevented a survey of all associations. Data collection involved a three stage sampling strategy. In the first stage, key areas of residential concentration of Capeverdeans were identified in the GLA. In a second stage, a listing of Capeverdean associations was constituted. This list was based on national and local official directories as well as on information gathered from non-governmental organisations listings and from long-established Capeverdean associations and community leaders. Of a total of 40 associations operating in the GLA, the overwhelming majority (35) is concentrated in these 3 municipalities. That is, 13 in Lisbon, 15 in Amadora and 6 in Oeiras. In the third stage, a questionnaire was applied to 22 of this total of 35 organisations. Thirteen organisations were deleted from the list for the following reasons: i) 2 of them were organisations which did not meet the established criteria of an ethnic association; ii) 5 were not operating at the time of the empirical work; iii) 1 was integrated in another Capeverdean association; iv) another 1 ceased its activities due to a neighbourhood re-housing project and v) 4 are basically "paper organisations" with which it was not possible to establish contact. Still the level of responses was quite high in the 3 municipalities, that is $46 \%$ in Lisbon; $73 \%$ in Amadora and $50 \%$ in Oeiras.

The questionnaire was administered by using a face-to-face interview method with the board members of the organisations. We followed the definition used by Fennema (2004) in the selection process of Capeverdean ethnic associations. Were considered as Capeverdean associations all non-profit organisations with a formal structure, a mission statement directed towards the Capeverdean migrant group and governing board in which at least half of the members are Capeverdeans. We also considered those organisations which half of the membership is of Capeverdean origin, independently of board constitution and mission statement. The overwhelming majority of the organisations interviewed in the 3 municipalities met the first set of criteria and only very few had less than half of Capeverdeans in the governing board and a mission statement directed towards all migrants.

Lastly, municipality officials and policymakers were also interviewed (semistructured interviews were conducted in Lisbon, Amadora and Oeiras) to assess the type and nature of policies being implemented at the local level, targeting immigrant populations. 


\section{THE ORGANIZATIONAL STRUCTURE OF CAPEVERDEAN ASSOCIATIONS IN LISBON, AMADORA AND OEIRAS}

Before analysing the social capital of the Capeverdean associations, it is important to describe the features of the Capeverdean organizational fabric in Lisbon, Oeiras and Amadora. To analyse the organizational characteristics of the associations interviewed, we consider the following set of indicators: number of organisations, type of organisations, the nature and scope of activities, size, membership, resources and mobilization capabilities.

\section{The nature and scope of associations' activities}

As table I indicates, the activities of Capeverdean associations are relatively diversified and target a wide range of issues. For the last year, the majority of associations ranked the areas of social assistance, education and youth as the most important. No significant differences were registered between municipalities. Although immigration issues were a privileged area of intervention of just 1 organization in Lisbon, more than half of the associations in this municipality and Amadora reported having organised activities concerning immigration. Politics, discrimination, human rights and humanitarian questions amounted to a small part of their agenda in the last year.

Table I - Priority areas of activity in the last year.

Quadro I - Áreas de actuação prioritária das associações no último ano.

\begin{tabular}{lcccccccc}
\hline & \multicolumn{2}{c}{ Lisboa } & \multicolumn{2}{c}{ Amadora } & \multicolumn{2}{c}{ Oeiras } & \multicolumn{2}{c}{ Total } \\
& $\mathbf{N}$ & $\mathbf{\%}$ & $\mathbf{N}$ & $\mathbf{\%}$ & $\mathbf{N}$ & $\mathbf{\%}$ & \multicolumn{1}{c}{$\mathbf{N}$} & \multicolumn{1}{c}{$\%$} \\
\hline Social Assistance & 2 & 25,0 & 1 & 9,1 & 1 & 33,3 & 4 & 18,3 \\
Health & 1 & 12,5 & 1 & 9,1 & & & 2 & 9,1 \\
Education & 1 & 12,5 & 2 & 18,2 & & & 3 & 13,7 \\
Capeverdeans Issues & - & & 1 & 9,1 & & & 1 & 4,5 \\
Youth & 1 & 12,5 & 3 & 27,2 & & & 4 & 18,3 \\
Culture, Music & 1 & 12,5 & - & & & & 1 & 4,5 \\
Hobbies/Leisure & - & & 1 & 9,1 & & & 1 & 4,5 \\
Community Developmentry & - & & - & & 1 & 33,3 & 1 & 4,5 \\
Employment & - & & 1 & 9,1 & & & 1 & 4,5 \\
Housing & - & & - & & 1 & 33,3 & 1 & 4,5 \\
Immigration & 1 & 12,5 & - & & & & 1 & 4,5 \\
Other & 1 & 12,5 & - & & & & 1 & 4,5 \\
No response & - & & 1 & 9,1 & & & 1 & 4,5 \\
\hline Total & 8 & 100,0 & 11 & 100,0 & 3 & 100,0 & 22 & 100,0 \\
\hline
\end{tabular}

In general terms, the majority of Capeverdean associations define themselves as social solidarity (welfare) organisations and only $27 \%$ as immigrant or cultural associations. There are, however, significant differences accord- 
ing to the local in which the associations operate. In Amadora and Oeiras, municipalities where the residential function of the Capeverdeans is dominant, the overwhelming majority of the associations has locally based interventions and classifies their activities in the category social assistance. Youth/sports and neighbourhood improvement/assistance, the other categories used to self-describe the activities of the associations in Amadora and Oeiras, also point to specific local targets.

Looking to the Lisbon-based associations, we find that the majority of them defined themselves as either cultural or immigrant associations, which points out a broader perspective of intervention, aiming at the whole group of Capeverdeans and not specific spatial or social sub-groups of total Capeverdean population. The self-definitions seem to point to a dichotomised organizational fabric, dominated by locally-based associations, targeting specific populations in the peripheries and "umbrella"/transversal associations in the city of Lisbon.

Another indicator of organisations' self-identity has to do with representation. When asked if they represented a particular group of people, only $22 \%$ of organisations indicated Capeverdeans. Forty percent of the respondents did not perceive the association as catering to a specific population. As we see in table II, there are significant differences in the groups being represented by the associations in the 3 municipalities. Whereas in Lisbon, the associations perceive themselves as representatives of Capeverdeans in general or of people coming from two specific geographical areas (Island of Fogo and Tarrafal in the Island of Santiago), in Amadora and Oeiras representation is not based primarily on in-group identification. Instead, Capeverdean associations tend to perceive themselves as representatives of a wider and more diversified group of persons namely Africans, neighbourhood residents and immigrants in general. In these last cases, membership criteria is more anchored in local belonging processes associated to the share of problems of destination places (the community of neighbours; the African residents of a specific multi-ethnic place) than in the original geographical identity.

From these results, the picture that emerges is that the activities of associations are a major determinant of their self-identification. Furthermore, the nature and scope of Capeverdean associations' activities is context-bound. In Amadora and Oeiras, organisations function mainly as locally-based welfare agencies combining social services with cultural and recreational activities. Their self-understanding relies heavily on social and community care rather than on cultural identity. It is important to stress that the overwhelming majority of the associations in these 2 municipalities are institutions of social solidarity that work in ethnically heterogeneous deprived neighbourhoods. In Lisbon, on the other hand, self-identification is based on a common geographical identity and on shared cultural and ethnic traits. Capeverdean associations in Lisbon tend to aim at a combination of cultural activities and social services while promoting migrants' interest representation. 
Table II - Groups of People being represented by the organisations in Lisbon, Amadora and Oeiras.

Quadro II - Grupos mais representados pelas organizações em Lisboa, Amadora e Oeiras.

\begin{tabular}{lcccccrrr}
\hline & \multicolumn{2}{c}{ Lisboa } & \multicolumn{2}{c}{ Amadora } & \multicolumn{2}{c}{ Oeiras } & \multicolumn{2}{c}{ Total } \\
& $\mathbf{N}$ & $\mathbf{\%}$ & $\mathbf{N}$ & $\mathbf{\%}$ & $\mathbf{N}$ & $\mathbf{\%}$ & \multicolumn{1}{c}{$\mathbf{N}$} & \multicolumn{1}{c}{$\%$} \\
\hline Capeverdeans & 3 & 37,5 & - & & - & & 3 & 13,7 \\
African community & - & & 2 & 18,2 & - & & 2 & 9,0 \\
Neighbourhood residents & - & & 2 & 18,2 & 1 & 33,3 & 3 & 13,7 \\
Immigrants & - & & 2 & 18,2 & 1 & 33,3 & 3 & 13,7 \\
Fogo born & 1 & 125, & 0 & & - & & 1 & 4,5 \\
Tarrafal born & 1 & 12,5 & 0 & & - & & 1 & 4,5 \\
No response & 3 & 37,5 & 5 & 45,4 & 1 & 33,3 & 9 & 40,9 \\
\hline Total & 8 & 100,0 & 11 & 100,0 & 3 & 100,0 & 22 & 100,0 \\
\hline
\end{tabular}

\section{Organizational Characteristics}

The overwhelming majority of the associations were founded in the $1980 \mathrm{~s}$ and only $22 \%$ were created after the mid 1990s. The oldest associations are located in Lisbon and in Amadora. The establishment of Capeverdean migrant associations in Amadora in the early 1980s is linked to the development of associational activism, led by the Capeverdean Association in Lisbon. From 1982 to 1989, this organization was responsible for the implementation of a major social intervention programme (JUNTAMON) financed by the World Health Organization. The project targeted mainly migrant populations living in slum neighbourhoods. Local mobilization and social intervention led to the creation of a considerable number of grassroots organisations operating in squatter settlements in Amadora and in other municipalities in the metropolitan area of Lisbon as well as in Oporto. In Amadora some of the initial associations have been transformed into private institutions of social solidarity (IPSS), and the overwhelming majority is operating at the local neighbourhood level. In Oeiras, Capeverdean migrant activism gains momentum only in the 1990s and, with very few exceptions, has been tied to slum neighbourhoods and to the slum clearance programme (PER) (Marques, Santos and Ralha, 1999; Marques et al., 2001).

\section{Membership and mobilization capacity}

Total and active membership in Lisbon is larger than in Amadora and Oeiras, reaching average values of more than 500 total members and 82 active members (if we don't consider the association of the Tarrafalenses in Portugal which surprisingly reported as having more than 3000 members). If ECC-CO is not taken into account, the associations in Oeiras had the lowest scores in all three categories. The major differences between the organisations in Lisbon and 
Amadora relate to the rate of non-member participants, much higher in the second case. As it was above mentioned, some associations in Amadora are private social solidarity institutions settled in ethnically heterogeneous slum neighbourhoods and developing activities potentially targeting all resident population. This situation justifies a higher degree of involvement of the local residents in the activities offered (sports, training, children assistance...) and tends to lead associations to consider all neighbourhood residents as potential participants in the organization's activities.

The analysis of the clientele of these organisations is in accordance with the situation we have just described. Whereas in Lisbon the average number of people catered by Capeverdean associations is 71, in Amadora and Oeiras the average scores are 2.337 and 767 respectively. In the case of Amadora, 2 associations indicated that they provide services to more than 8.000 people. Also in Oeiras, ECC-COs total clientele surpasses 2.000 persons. Overall, if local associations tend to consider the total population of the neighbourhood in which they operate as their constituency, entities which define themselves as cultural or sports organisations target specific groups and have a much more limited sphere of intervention.

The mobilization capacity of the organisations settled in Amadora and Oeiras is also in line with the aforementioned findings. This analysis, that considers Real Mobilization Capacity (Real M.C.) ${ }^{7}$ and Potential Mobilization Capacity (Potential M.C.) ${ }^{8}$, shows that real mobilization capacity of the associations in Amadora and Oeiras almost doubles that of Lisbon. In the 3 municipalities the initiatives that attracted more participants were Christmas Feasts, Cabo Verde Independence Day, Diaspora Congress in Cabo Verde, Immigrant Census Campaigns and Youth and Health activities.

In broad terms, these results reflect the different types of organisations and the breath of their membership that is context-bound and cutting across ethnic affiliations, especially in the cases of the neighbourhood-based associations of Oeiras and Amadora.

\section{Human and Financial Resources}

The associations in Amadora have at their disposal a greater amount of human and financial resources than the organisations operating in the other 2 municipalities. For instance, in Amadora 3 associations indicated a total annual budget over 200.000 Euros. If these organisations are not taken into account, the average budget is 49.000 Euros. In Lisbon and in Oeiras the scores are

7 Corresponds to the number of participants in the activity or initiative organized during the last year which gathered more people.

8 Corresponds to the maximum number of people the associations thought possible to mobilize. 
24.000 Euros and 43.000 Euros respectively. Also the sources of finance are rather different. Whereas in Lisbon the sources of revenue come basically from membership fees, national subsidies and the sale of goods and services, in Amadora the majority of the organisations are financed by public monies (provided by national institutions and to a lesser extent by local authorities) and even EU funds. This points to higher technical and human capacities of some Amadora organization, which seem more capable to mobilize national and EU resources.

Overall, the analysis of the resources available in the organisations researched discloses a higher offer of social service delivery schemes for the majority of Amadora associations, which is associated to a stronger level of institutional imbrication. In fact, more than $50 \%$ of the associations in this municipality are private social solidarity institutions with access to a larger pool of human and financial resources than other ethnic organisations. In Lisbon and in Oeiras the situation is rather different because none of the associations are private institutions of social solidarity.

\section{DENSITY OF THE ORGANIZATIONAL NETWORK: RELATIONAL DIMENSIONS OF SOCIAL CAPITAL}

As mentioned before, the social capital of the associations, analysed in terms of the nature and intensity of the organizational relations, is very much tied to the connectivity of the different associations between themselves and with other organisations. Four major dimensions are considered: 1. the relations of associations with non-immigrant organisations; 2 . the relations of associations between themselves; 3 . identification of the strongest connections in the associational network, and 4. transnational relations.

\section{Inter-Organizational Networks: developing "bridging ties" with the local/national institutional fabric}

To assess the level of integration of Capeverdean associations in the local and national organizational network, associations were asked to name the noncapeverdean organisations with which they had some form of contact (meetings/consultation) and with which they had collaborated in the past two years.

Overall, the level of interaction with these organisations is very low in the 3 municipalities. It is evident that in the 3 municipalities the associations had contacts with charitable organisations, with NGOs targeting immigrant issues, national institutions such as the High Commission for Immigration and Ethnic Communities (ACIME) and The Portuguese Council for Refugees. ACIME ranks first in terms of collaborations. This is mainly due to the fact that several associations interviewed are recognised by ACIME and members of its Consultative Council for Immigration Issues. 
In Amadora, relations with charitable organisations are particularly evident, which is not surprising given the high number of Capeverdean migrant organisations which function as social services agencies. The involvement with neighbourhood organisations is very weak. Of particular interest are the relations established with political parties especially with the two Portuguese major parties: socialist party $(P S)$ and the social democrat party $(P S D)$. A close contact with political parties seems to reflect the overall local political structure that has been mainly channelled to local political partisanship. Local agents tend to solve local administrative problems through their own informal connections and partisan networks rather than through official local interest groups. The relational network of migrant Capeverdean associations with political parties tends to reflect the local model. For some associations, political parties are viewed as an important means to access scarce resources. In addition, political parties tend to lobby migrant associations, especially during local election campaigns.

Table III - Contacts of Capeverdean associations with non-immigrant associations in the municipalities of Lisbon, Amadora and Oeiras.

Quadro III - Contactos das Associações Cabo-verdianas com associações não imigrantes em Lisboa, Amadora e Oeiras.

\begin{tabular}{lcc}
\hline Lisbon & $\begin{array}{c}\text { Meetings/ } \\
\text { Consultation }\end{array}$ & Collaboration \\
\hline Associação Caboverdiana & 23 & 13 \\
Organização de Quadros & 10 & 0 \\
Morabeza & 8 & 8 \\
Morna & 5 & 2 \\
Tarrafalenses & 1 & 1 \\
Amifogo & 1 & 1 \\
Amadora & & \\
Moinho da Juventude & 19 & 4 \\
Clube D Cova da Moura & 19 & 3 \\
Centro Social 6 de Maio & 10 & 10 \\
Unidos de Cabo Verde & 9 & 6 \\
Espaço Jovem & 6 & 1 \\
Oeiras & & 4 \\
ECC-CO & 5 & 0 \\
Assomada & 4 & \\
A.M. Outurela/Portela & 5 & \\
\hline
\end{tabular}

Another dimension of associations' interrelational networks refers to the centrality of organisations in the web of relations with non-immigrant organisations. Table III shows that in Lisbon, the Capeverdean association is by far the organization with a highest level of integration in the local organizational networks, Morabeza ranks second followed by Morna. In Amadora, 
although 2 associations have mentioned a large number of contacts, the number of collaborations is rather limited. When the number of collaborations is taken as the major indicator for organisations' integration, the Social Centre 6 de Maio, the Associação Unidos de Cabo Verde and the Association Moinho da Juventude have the highest level of integration in local associational networks. All these associations are social services organisations that tend to collaborate more closely with charities and with other NGOs involved with immigrant and refugee issues. Cultural and recreational associations in Lisbon and Amadora have very few contacts and hardly any collaboration with local non-immigrant organisations. Finally, in Oeiras, ECC-CO and Assomada are the 2 associations with more links with local non-immigrant associational networks.

\section{Intra-organizational Networks - The relevance of "bonding ties"}

Table IV shows the connectivity between associations in the 3 municipalities. One striking feature is that, in general, there is a discrepancy between the number of contacts declared and the number of contacts confirmed. Given this situation, the centrality of associations is measured by the number associations which mention a specific partner.

The dominant role of the Capeverdean Association in the Capeverdean associational movement in the Metropolitan Area of Lisbon is impressive. The association's inter-organizational contacts with non-immigrant organisations are almost three times higher than those indicated by the remaining associations. A similar pattern is evident in the intra-organizational relations. The number of associations with which the Capeverdean Association had some type of collaboration in the last two years is substantially higher than those registered by other organisations, including Morabeza and Unidos de Cabo Verde which rank second and third in organizational intra-relational networks.

Actually, after the position of the Capeverdean Association, which is the top node of the capeverdean institutional structure, we can identify a group of second level nodes that comprehend precisely Morabeza and Unidos de Cabo Verde and also the Associação de Antigos Alunos (AA-CV) and the Clube Desportivo Cova da Moura. However, the placement of these last 2 organisations in the second level is associated to their very specific nature that facilitates networking processes. On the one hand, the $A A-C V$ gathers former Capeverdean students - some of them members of other associations - and has become a reference for several of them (remarkably, in this case, contacts confirmed are much higher than contacts declared), relying its activity partially in the maintenance of the ties among this group of people. On the other hand, the diversified sports activities developed by the Clube Desportivo as well as the competitions where it is involved increase its visibility, contributing to its placement in the contacts hierarchy. 
Table IV - Total network connections of associations in Lisbon, Amadora and Oeiras.

Quadro IV-Conectividade das associações em Lisboa, Amadora e Oeiras.

\begin{tabular}{lcccc}
\hline & \multicolumn{2}{c}{ Contacts } & \multicolumn{2}{c}{ Colaboration } \\
\hline Associations & $\begin{array}{c}\text { Mentioned by } \\
\text { Capeverdean } \\
\text { associations }\end{array}$ & Declared & $\begin{array}{c}\text { Mentioned by } \\
\text { Capeverdean } \\
\text { associations }\end{array}$ & Declared \\
\hline Associação Caboverdiana & 17 & 22 & 12 & 19 \\
\hline Morabeza & 14 & 11 & 8 & 11 \\
Unidos de Cabo Verde & 11 & 11 & 8 & 11 \\
C D Cova da Moura & 10 & 28 & 8 & 8 \\
Antigos Alunos SCV & 11 & 3 & 7 & 7 \\
ECC-CO & 10 & 19 & 4 & 6 \\
Moinho da Juventude & 10 & 13 & 5 & 5 \\
Assomada & 10 & 12 & 4 & 5 \\
Congresso de Quadros & 10 & 11 & 6 & 0 \\
Mão Unidas & 10 & 7 & 5 & 5 \\
Espaço Jovem & 8 & 10 & 6 & 2 \\
\hline Amifogo & 7 & 5 & 3 & 5 \\
Amigos do Concelho & & & & 4 \\
$\quad$ de S.Miguel-CV & 6 & 12 & 4 & 11 \\
AJPAS & 5 & 13 & 4 & 4 \\
\hline
\end{tabular}

It is also important to stress that the two first levels of the nodal structure are dominated by Lisbon-based organisations, with the exception of Unidos de Cabo Verde and also of the aforementioned Clube Desportivo da Cova da Moura. Therefore, it becomes clear a distinction between the more grassroots-based neighbourhood organisations of the peripheral municipalities (corresponding to nodes placed below level two of the hierarchical connection structure) that are closer to the populations and display a relatively high mobilization capacity and the more central organisations that play structuring roles in the Capeverdean organizational fabric, even if they are more distant of the populations.

Finally, it is worth mentioning the differential levels of organizational density concerning intra and inter-organizational networks of the associations interviewed. The density of networks between Capeverdean associations is considerably higher than the density of relations established with non-immigrant organizational structures. When cross-ethnic networks are taken into account, only 2 associations in Lisbon mentioned contacts with other ethnic organisations, more specifically with a Guinean association (AGUINENSO) and with the Brazilian association (Casa do Brasil). Only 1 association in Oeiras had contacts with Casa do Brasil. In Amadora, 6 associations indicated to have contacts with AGUINENSO and only 3 with Casa do Brasil. The fact that a great number of associations in Amadora cater to ethnically heterogeneous associations may explain a high incidence of contacts with other ethnic organisations. Still, these contacts are very limited and focussed only on two ethnic groups, the Guineans and the Brazilians. 


\section{Transnational Networks - the long distance "bridging ties" (the bridging II form of social capital)}

One last dimension of organizational networks concerns the density of international contacts. The overwhelming majority of associations do not have any contacts with international organisations. Of those who maintain some type of cross-national relations, religious institutions, political and international interest organisations rank first. However, the results are rather distinct when inquired about their contacts with foreign-based Capeverdean associations. Eighty-eight percent of the associations interviewed had linkages with Capeverdean organisations operating all over the world, and the average number of contact institutions for the associations in Lisbon, Amadora and Oeiras are 1.6, 2.1 and 1.3 respectively. Privileged links were found with Capeverdean associations in The Netherlands (Avanço and Capeverdean Association of the Netherlands, both in Rotterdam), Italy (Capeverdean Women Organization of Italy, and Capeverdean Association of Italy) and France (Capeverdean Associations in Nice, Lyon and Paris), the three other major destinations of the Capeverdean diaspora in Europe.

Another dimension of border-crossing relations corresponds to the contacts established with local and national organisations operating in Cape Verde. At a local level, sports, cultural and youth associations are most mentioned whereas at the national level the linkage is exclusively with the Institute of Capeverdean Communities. The existence of a large and well organised diaspora provides Capeverdean associations with further possibilities for pooling resources as well as to reinforce ethnic collective identity, both important factors of social capital.

\section{The relational space of organisations - key elements}

In sum, four major features emerge from the above discussion. First, a certain distinction between central associations placed in Lisbon (e.g. Associação Caboverdeana, Morabeza, Antigos Alunos) which play the role of organizational nodes and the neighbourhood-based associations that work as social service providers and display higher levels of local imbrication and mobilization capacity may be found. Second, the density of inter-organizational networks is quite low among Capeverdean associations. Even so, associations tend to privilege contacts with charity associations, national institutions concerned with immigration issues and political parties. Third, concerning intra-organizational relations, the associations with the highest density of out-group contacts are also the ones that have a denser network of in-group contacts. That is in-group relations are favoured to out-group relations. Also, cross-ethnic ties with other immigrant groups are not frequent and apparently limited to Brazilian and Guinean organisations. Finally, transnational networks are directed towards the Capeverdean organisations in the Diaspora. Associations tend to play in the transnational field, expanding the scope of their activities while strengthening ethnic identification as well as group solidarity. 


\section{POLITICAL PARTICIPATION}

The political participation of associations is analysed through the evaluation of the political engagement in different types of activities, including protest actions or other less confrontational forms of activities (petitions, propaganda, media conferences, etc), participation in election campaigning as well as the involvement with local political structures. In addition, the participation of associations' members in local consultative bodies will also be examined. This attempt to identify the associations that have the highest levels of political participation aims to assess the interaction between organizational social capital and political activities

Table $\mathrm{V}$ indicates differences in the area of participation in protest actions between the associations based in different municipalities. These results suggest that immigration, citizenship rights and economic and social issues tend to mobilize a greater number of associations. Still, there are significant differences between the concelhos. As one may expect, in Amadora problems facing populations living in poor and marginalized neighbourhoods (poverty, drugs, crime, unemployment, education and racial discrimination) are at the centre of nonconfrontational protests. Also, claims-making demands in the public domain on the recognition of cultural difference and heritage minority cultures are particularly evident in both Lisbon and Amadora. In the city of Lisbon, citizenship rights and cultural politics are major issues for collective mobilization.

In broad terms, associations seem to give more favourable support to integration issues than to religious or international issues. When conventional and more "violent" forms of protest are considered, the general picture that emerges is that associations refrain from violent actions (for example lock ups and strikes) and prefer "softer" forms of claims-making such as media conferences, petitions or demonstrations (table VI).

Furthermore, the intensity of action repertoires of associations varies considerably from municipality to municipality. An important difference is the high frequency of symbolic non-confrontational forms of protest in the case of Lisbon. This finding confirms the expectations that associations in Lisbon would be more exposed to protest demonstrations given that the local and national contexts intersect in this municipality and, consequently, the number of protest actions tends to be higher. The data also shows that more conventional forms of protest such as petitions and media conferences are more frequent in Amadora and Oeiras.

It is important to mention that the associations which constituted nodal points of reference in inter- and intra-organizational networks are precisely those with the highest level of political participation activities, namely Capeverdean Association and Morabeza, but also the Cultural Association Moinho da Juventude and the Social Centre 6 de Maio. The association Unidos de Cabo Verde is the only exception. This organization ranked high both in inter- and intra-organizational networks but its political demands actions are not significant. In the 
Table V - Percentage of associations involved in protest actions by issues. Quadro $V$-Percentagem de associações que têm participado em acções de protesto, por temas.

\begin{tabular}{lccc}
\hline Type of Protest Actions & Lisbon & Amadora & Oeiras \\
\hline Housing & 12 & 27 & 0 \\
War/Defence & 0 & 54 & 0 \\
International Politics & 0 & 0 & 0 \\
Political Development in other countries & 25 & 0 & 0 \\
Defence of minorities' traditional life styles & 50 & 63 & 33 \\
Quality or access to education & 25 & 54 & 0 \\
Racial Harassment/discrimination & 0 & 36 & 0 \\
Citizenship rights & 25 & 54 & 33 \\
Asylum & 0 & 9 & 0 \\
(Un)employment issues & 25 & 36 & 0 \\
Poverty & 25 & 45 & 0 \\
Fighting crime in local neighbourhood & 12 & 63 & 0 \\
Religious rights & 0 & 18 & 33 \\
Fighting drugs & 25 & 45 & 33 \\
Police behaviour & 0 & 18 & 33 \\
Homelessness & 0 & 18 & 0 \\
Immigration policies & 62 & 45 & 33 \\
\hline
\end{tabular}

Table VI - Percentage of associations which participated in political activities by type of activity.

Quadro VI - Percentagem de associações que têm participado em actividades políticas, por tipo de acção.

\begin{tabular}{lccc}
\hline Type of Protest Actions & Lisbon & Amadora & Oeiras \\
\hline Demonstrations & 25 & 60 & 33 \\
Petitions & 75 & 90 & 100 \\
Media contacts & 25 & 36 & 66 \\
Lock ups & 0 & 0 & 0 \\
Strikes & 0 & 10 & 0 \\
\hline
\end{tabular}

last twelve months they have not been involved in any of the above mentioned activities except in the organization of a public demonstration.

Overall, these results suggest that those organisations with higher organizational density and, thereby, with more social capital are also those with higher levels of political activities. These results also point out the need for conducting further research on whether these political activities translate a high degree of trust in the political system in general and in political institutions in particular.

Another dimension of great importance is the capacity of associations to promote the participation of their members in election processes. Associations were inquired about their participation in election campaigns as well as whether their members were elected. As table VII illustrates, the majority of associa- 
tions in the municipalities of Lisbon and Amadora are directly involved in political campaigns and some associations were successful in having candidates elected, which confirms the links found between associations and political parties. Oeiras is the exception. As one might expected, data also shows that immigrant associations in Lisbon have a higher level of political participation in regards to member candidates and members elected in the different political spheres.

Table VII - Percentage of associations engaged in election activities. Quadro VII - Percentagem de associações que participam em actividades eleitorais.

\begin{tabular}{lccc}
\hline & Lisbon & Amadora & Oeiras \\
\hline Participation in election campaigns & 50 & 64 & 0 \\
Candidate in local elections & 45 & 45 & 67 \\
Candidate in regional elections & 0 & 9 & 0 \\
Candidate in national elections & 50 & 0 & 0 \\
Candidate in elections country of origin & 50 & 13 & 33 \\
Elected candidate in local elections & 38 & 45 & 33 \\
Elected candidate in regional elections & 0 & 9 & 0 \\
Elected candidate in national elections & 50 & 0 & 0 \\
Elected candidate in country of origin & 38 & 0 & 0 \\
\hline
\end{tabular}

Another important finding relates to transnational politics and the ways in which immigrant organisations in the receiving country interact with homeland political spaces. Several migrant organisations have been (and still are) linked up to political parties in the country of origin. For example, the Capeverdean Association has been associated with the (PAICV - African Party for Independence of Cape Verde) whereas $E C C$ - $C O$ has had a close relationship with the Capeverdean opposition party, the $M p D$ (Movement for Democracy). Also other migrant associations have been either implicitly or openly associated with the political parties in power. For the political parties in the country of origin the involvement of migrant associations has been instrumental not only for the mobilization of large constituencies abroad ${ }^{9}$ but also for the pooling of social, economic and political resources. Competition and the consolidation of home country political parties have transcended national territorial boundaries expanding its scope of action to "diasporic" communities. Migrants' engagement with the country of origin can hardly be reduced to partisan politics. In the last decade, Capeverdean governments have devised multiple incentives to maintain and reinforce the linkages between the Capeverdean diaspora spread all

9 Capeverdean nationals settled abroad have the right to vote in the elections for the National Parliament and the President of the Republic. 
over the world and Cape Verde. New institutional channels for the representation of Capeverdean emigrants in the parliament were created to incorporate migrants' constituencies. For instance, the recently constituted Instituto das Comunidades (Institute for Communities) is perceived as a major policy instrument targeting communities abroad. Foreign investment, migrants' remittances, recruitment of Capeverdean professionals in the diaspora, pooling of social resources and technological know-how are major objectives of a policy which articulates emigration, national development and citizenship.

A last finding has to do with participation in local consultative bodies at the municipal level. The overwhelming majority of the associations were not invited to participate in local advisory councils and very few are members of consultation committees or task groups addressing specific policies or issues. Only $18 \%$ of the organisations are permanent members of a municipal council on specific issues such as immigration and social services. It is important to note that only the municipalities of Lisbon and Amadora have advisory councils for immigrant and ethnic minorities' affairs. National and local institutions, operating as liaisons between political structures and migrants are very few and tend to have a limited scope of action. To this extent institutional frameworks have not shown so far a great deal of openness to migrants' participation in policy-making nor have they function as effective forms of activation of immigrants' political integration.

In Portugal, migrant ethnic groups are not officially or judicially recognized as specific categories or collective groups. Moreover, ethnicity is not a relevant criterion for the inclusion (or exclusion) of immigrant groups in the formal political system. Instead, a more individual oriented approach has been adopted in dealing with migrants' integration in the Portuguese society. At a local level, linking to immigrant groups has thus not implied the creation of specific formal channels for their integration in municipal political structures. Instead, immigrants' consultation and engagement in policy-making is not based on ethnic traits but on the nature of migrants' associational activities be they cultural recreational, social services, sports, leisure or youth. In the local field in which political partisanship and (in)formal networks become a dominant form of capital, migrant grassroots-based associations tend to maximize their social and economic capital by drawing upon all the resources available to them. Informal contacts, short-term alliances with municipal authorities and participation in local government sponsored programs are major strategies used by these organisations to capitalize on public funds and to increase their capacity to influence local policymaking.

\section{CONCLUDING REMARKS}

Although there are many differences between Capeverdean organizing processes in the 3 municipalities, the findings also show some important pat- 
terns in the organization structure and in ethnic civic engagement. First, and in regards to organizational structure of Capeverdean associations, the picture that emerges is that the majority of associations are small-scale operations which orient themselves towards social services. Major differences were identified between associations in Lisbon and in Amadora and Oeiras. In these 2 latter concelhos, associations are mainly grassroots-based organisations that function as social services agencies for their local constituencies privileging neighbourhood-bonding ties. In Lisbon, organised migrant activity target immigrant and cultural issues with a combination of social care activities.

Also, the mobilization capacities and nature and scope of intervention are very much linked to the organizational model of associations. Organisations operating in migrant neighbourhoods tend to have a large capacity to mobilize their constituencies than those functioning in Lisbon. Furthermore, representation modes are context-bound. Local organisations tend to represent wider and ethnically heterogeneous groups while in Lisbon representation is particularly linked to Capeverdean ethnic affiliation, assuming a top-ranking role in the institutional Capeverdean fabric.

Second, concerning inter-organizational relations the overall level of interaction with non-immigrant agencies is very low, which points to a low-level of "bridging I social capital" (the sub-dimension associated to the relations with the representatives of other groups). Associations' privilege contacts with ACIME, charity organisations, NGOs catering to immigrants' issues and political parties. In the same line, cross-ethnic institutional relations are also very limited. This does not necessary mean that Capeverdean associations tend to isolate themselves from mainstream society. What these findings seem to reveal is that associations tend to respond to the political opportunity structures they face. The scarcity of institutional frameworks and of a wide range of mechanisms promoting the active participation of ethnic organisations in Portuguese society are major factors that should be taken into account in order to explain differential levels of social and political integration.

Third, a different picture emerges when intra-organizational relations are considered. The density of relations between associations is far superior to those registered in the inter-organizational field. Four major nodal reference points were identified in the wide web of network contacts. The associations that tend to have more inter-organizational contacts are also the associations with the highest level of intra-organizational relations. In addition, the overwhelming majority of associations are involved in the diaspora transnational field. Although it was not possible to ascertain the qualitative nature of transnational contacts, the presence of border-crossing social networks will tend to enhance the ability of individuals to mobilize a set of resources and, thereby, increase the social capital drawn from this web of relationships. Also, the coexistence of political orientations towards the country of origin and the receiving society among migrant ethnic groups is not peculiar to Capeverdean immigrants. In fact, it has been well documented the overlapping of "homeland politics" and "immigra- 
tion politics" as different but related dimensions of migrants' transnational political practices. (Ostergaard-Nielsen, 2003).

Overall, when looking at the nature and density of organisations' networks, "bonding social capital" seems to be much higher than "bridging social capital I" (the type associated to the relations with representatives of other groups), that only increases its relevance in the case of some Lisbon "umbrella" associations. As far as "bridging II social capital" is concerned, the involvement of several associations in the transnational space of the Capeverdean diaspora points to its importance, still further research is required to ascertain these first findings.

Fourth, the political engagement of associations reflects an overall tendency towards non-confrontational forms of claims-making. Demonstrations, petitions, public statements and media contacts are favoured to strikes, lockups or to other more "violent" activities. Overall, their protest activities focus on integration, citizenship and immigration issues. Problems related to dailylife in poor neighbourhood tend to mobilize associations in Amadora whereas in Lisbon more broad legal and judicial issues such as citizenship rights and immigration laws are at the centre of the protest activities. These differences are closely linked with the specific social contexts in which these associations operate as well as to the differential roles they play in the Capeverdean institutional fabric (structural/umbrella organisations in Lisbon; more grassroots structures in the peripheral municipalities). Also of importance is the participation of associations in the political institutional framework. In broad terms, the majority of associations is involved in local political campaigns and shows the capacity to mobilize their members to participate actively in the political process. In Lisbon, candidates were elected at the local and national levels as well as in the country of origin. This signals associations' involvement in multiple national and international political fields, revealing the ability of immigrants' to act politically with respect to the receiving country as well as to the homeland.

Finally, these findings tend to support the assumption that ethnic civic engagement potentiates political participation. The data shows that associations with higher social capital that is with the densest network of organizational relations are also those that participate the most in political activities, be they protest actions or election campaigning. The evidences also illustrate that social capital of ethnic associations is not directed exclusively towards civic engagement in the receiving country. Ties with other associations in the diaspora and the involvement with homeland politics attest to the ways in which social capital is convertible into different types of political and civic engagement. However, further research is required to explore the extent to which this relationship is mediated by the presence of ethnic leaders with particularly strong ties to the formal political system in the country of origin as well as with the receiving country (the individual social capital). Still Capeverdean associations seem to function as an important mediating factor in the political involvement of migrants. 
By channelling claims-making into non-violent forms of protest as well as by potentiating social capital and civic engagement in receiving country and in the country of origin, the associational movement plays an important role in the integration process of Capeverdeans.

\section{ACKNOWLEDGEMENTS}

The authors thank the Foundation for Science and Technology (FCT) for its grant support to the research project Comunidades Migrantes, Cidadania e Participação Política: A Diáspora Cabo-verdiana em Portugal e na Holanda $/ A G O R A$, under the auspices of the Centre for Migration and Intercultural Relations/CEMRI, Universidade Aberta. The authors are also grateful to the partners of the international network Multicultural Democracy in European Cities: Political Integration, Communities, and Local Government Policies, University of Amsterdam, specially to Meindert Fennema and Laura Morales Diez de Ulzurrun for their valuable insights and collaboration, and to Paulo Costa, Universidade Aberta, for his most helpful research assistance.

\section{BIBLIOGRAPHY}

Anderson U (1990) Consultative institutions for migrant workers. In Layton-Henry Z (ed.) Political Rights of Migrant Workers In Western Europe. Sage, London: 113-126.

Baernholdt J, Aarsother N (2002) Coping strategies, social capital and space. European Urban and Regional Studies, 9(2): 151-165.

Bousetta H (1997) Citizenship and political participation in France and the Netherlands: Reflections on two local cases. New Community, 23(2): 215-231.

Embaixada de Cabo Verde em Portugal/IESE/Geoideia (1999) Estudo de caracterização da comunidade caboverdeana residente em Portugal. Embaixada de Cabo Verde em Portugal, Lisboa.

Fennema M, Tillie J (1999) Political participation and political trust in Amsterdam: civic communities and ethnic networks. Journal of Ethnic and Migration Studies, 25(4):703-726.

Fennema M, Tillie J (2001) Civic community, political participation and political trust of ethnic groups. Connections, 24(1): 26-41.

Fennema M (2004) The concept of measurement of ethnic community. Journal of Ethnic and Migration Studies, 30 (3): 429-447.

Horta A P B, Malheiros J (2004) Os Cabo-verdianos em Portugal: processo de consolidação, estratégias individuais e acção colectiva. Estratégia, 20: 83-103.

Horta A P B, Matés R (2005) Políticas de imigração e o movimento associativo migrante em Portugal e em Espanha. Estudios Migratórios. Arquivo da Emigración Galega, Santiago de Compostela (forthcoming).

Instituto Nacional de Estatística (2001) Censo, 2001. INE, Lisboa. 
Jacobs D, Tillie J (2004) Introduction: social capital and political integration of migrants. Journal of Ethnic and Migration Studies, 30(3): 419-427.

Koopmans R, Statham P (2000) Migration and ethnic relations as a field of political contention:an opportunity structure approach. In Koopmans R, Statham P (eds) Challenging Immigration and Ethnic Relations Politics. Comparative European Perspectives. Oxford University Press, Oxford: 14-56.

Malheiros J, Vala F (2004) Immigration and city change: the region of Lisbon in the turn of the 20th century. Journal of Ethnic and Migration Studies, 30(6): 1065-1086.

Marques M, Santos R, Ralha T (1999) Divided cities: best practices for the social inclusion of ethnic minorities in local communities. IV Metropolis International Conference, Washington DC, 8-11 Dec., 14 p. (mimeo).

Marques M, Santos R, Marques Araújo F, Nóbrega S (2001) Realojamento no concelho de Oeiras, um estudo sociológico. Cadernos Técnicos de Habitação, n. ${ }^{\circ}$ 1, Direcção Municipal de Planeamento e Habitação, Oeiras.

Ostergaard-Nielsen E (2003) The politics of migrants. Transnational political practices. International Migration Review, 37: 760-786.

Penninx R et. al. (2004) Citizenship in European Cities. Immigrants, local politics and integration policies. Ashgate, London.

Putnam R (1993) Making democracy work. Civic traditions in modern Italy. Princeton University Press, Princeton, New York.

Putnam R (2000) Bowling alone. The collapse and revival of american community. Princeton University Press, New York.

Soysal Y (1994) Limits of citizenship: migrants and postnational membership in Europe. University of Chicago Press, Chicago.

Tillie J (2004) Social capital of organisations and their members: explaining the political integration of immigrants in Amsterdam. Journal of Ethnic and Migration Studies, 30(3): 529-541.

Vertovec S (1999) Minority associations, networks and public policies: re-assessing relationships. Journal of Ethnic and Migration Studies, 30(3): 529-541. 